PUSTABIBLIA: Journal of Library and Information Science

ISSN 2549-3493 (Print); ISSN 2549-3868 (Online)

DOI: http://dx.doi.org/10.18326/pustabiblia.v4i2.245-264

SK Dirjen Risbang-Kemristekdikti No 23/E/KPT/2019 (Peringkat 4 SINTA)

\title{
Layanan Kemas Ulang Informasi Berbasis Digital
}

\author{
Alwi Alfiana ${ }^{1}$, Samson CMS ${ }^{2}$ \\ ${ }^{1}$ Universitas Padjadjaran \\ ${ }^{2}$ Universitas Padjadjaran \\ e-mail:alwialfiana7@gmail.com,samson.cms@unpad.ac.id
}

\begin{abstract}
The increasing need for information in the present era is a problem for information provider institutions to continue making innovations in order to be able to provide relevant information in an attractive manner. On this basis, this research was conducted by finding out how the development of digital-based information services amidst the incessant information. Where in the current information era, every information institution is required to be able to provide interesting and reliable sources of information and be able to package it in an attractive and easily accepted form. The development of digital-based information services with an attractive method, namely repackaging information is an innovation that can be done. Where the purpose of this study is to determine the form of digital information services and the process in providing good service. The benefits of this research can be used to develop the concept of digital-based information services for libraries. The method used is a qualitative method with a descriptive approach. This method is a method in researching the status of human groups, an object, a set of conditions, a system of thought or a class of events in the present. This type of research data is taken through interviews and direct observation of related institutions, so that data can be obtained. a comprehensive range of variables presented. Data analysis was carried out through several steps such as preparing data instruments, data collection, data classification, data analysis and drawing conclusions. Data from interviews and observations were analyzed using qualitative methods to the variables used as research subjects. Based on the results of data analysis, it was found that information services could be developed attractively through information repackaging carried out by PDDI - LIPI through information repackaging services, namely industrial trees.
\end{abstract}

Keywords: Services, Library, Digital, information repackaging, PDDI-LIPI 


\begin{abstract}
Abstrak
Kebutuhan akan informasi di era sekarang yang terus meningkat menjadi persoalan bagi lembaga-lembaga penyedia informasi untuk terus membuat sebuah inovasi agar mampu memberikan informasi yang relevan dengan dikemas semenarik mungkin. Atas dasar inilah penelitian ini dilakukan dengan mencari tahu bagaimana pengembagan layanan informasi yang berbasis digital ditengah gencarnya informasi. Dimana pada era informasi saat ini setiap lembaga informasi dituntut untuk mampu memberikan sumber-sumber informasi yang menarik dan dapat dipercaya serta mampu mengemasnya dalam bentuk yang menarik dan mudah diterima. Pengembangan layanan informasi berbasis digital dengan metode yang menarik yaitu kemas ulang informasi merupakan suatu inovasi yang dapat dilakukan. Dimana tujuan penelitian ini adalah untuk mengetahui bentuk dari layanan informasi digital dan prosesnya dalam memberikan pelayanan yang baik. Manfaat penelitian ini dapat digunakan untuk menyusun pengembangan konsep layanan infromasi berbasis digital bagi perpustakaan. Metode yang digunakan adalah metode kualitatif dengan pendekatan deskriptif. Metode ini yang merupakan suatu metode dalam penelitian status kelompok manusia, suatu objek, suatu set kondisi, suatu sistem pemikiran ataupun suatu kelas peristiwa pada masa sekarang.Data jenis penelitian ini diambil melalui wawancara dan observasi secara langsung terhadap lembaga yang terkait, sehingga dapat diperoleh data yang komprehensif terhadap variabel yang disajikan. Analisis data dilakukan melalui beberapa langkah-langkah sepeerti mempersiapkan instrument data, pengumpulan data, klasifikasi data, analisis data dan penarikan kesimpulan. Data hasil wawancara dan observasi dianalis dengan menggunakan metode kualitatif terhadap variable yang dijadikan subjek penelitian. Berdasarkan hasil analisis data ditemukan bahwa layanan informasi dapat dikembangkan secara menarik melalui kemas ulang informasi yang dilakukan PDDI - LIPI melalui layanan kemas ulang informasi yaitu pohon industri.
\end{abstract}

Kata Kunci: Pelayanan, Perpustakaan, Digital, Kemas ulang informasi, PDDI- LIPI

\title{
1. PENDAHULUAN
}

Saat ini perkembangan dalam bidang teknologi menjadi semakin pesat dari waktu ke waktu. Hal ini membuat pertumbuhan teknologi di dunia kini tidak bisa lagi dihindari, khususnya dalam pertumbuhan teknologi di bidang informasi. Segala macam bentuk terobosan terbaru di bidang teknologi informasi bermunculan untuk memudahkan para pencari 
informasi untuk dapat secepat mungkin mendapatkan informasi yang diinginkan khususnya dalam memberikan pelayanan berbasis digital dalam memberikan sumber-sumber informasi yang terpercaya. Belum lagi tuntutan akan kebutuhan informasi dari masyarakat yang semakin meningkat setiap saatnya baik dalam bidang apapun itu. Kemajuan teknologi dan informasi dapat menjadi kekuatan atau pendorong bagi berbagai pihak terkait untuk mampu terus mengikuti perkembangan zaman sehingga mampu memenuhi kebutuhan akan informasi. Hal ini dikarenakan keadaan dunia saat ini yang semakin mengglobal secara tidak langsung telah memaksa setiap individu ataupun lembaga untuk dapat mempertajam pengamatannya terhadap informasi-informasi yang didapat, hal ini juga menuntut setiap individu ataupun lembaga untuk dapat meningkatkan kualitas agar dapat mengikuti perkembangan zaman. Berkembangnya teknologi saat ini juga turut memberikan dampak bagi bidang informasi, salah satu bentuk dari adanya perkembangan di bidang informasi adalah dengan adanya sumber-sumber informasi yang berbasis digital dimana pada dasarnya sumber-sumber informasi yang masih berbentuk cetak sudah mengalami alih media menjadi sumber bacaan elektronik yang dapat diakses oleh siapa saja dan dimana saja.

Bentuk dari adanya sumber-sumber informasi berbasis elektronik ini salah satunya adalah munculnya website yang memberikan pelayanan secara digital yang sudah semakin banyak kita jumpai jika mencari informasi melalui internet, tidak terkecuali perpustakaan. Hal ini menjadi alasan perpustakaan ini untuk dapat mengikuti zaman yang ada sekarang, yaitu dengan menjadi perpustakaan digital. Dimana dalam perpustakaan digital ini segala macam kegiatannya dilakukan secara digital, baik berupa pengadaan koleksi dengan digitalisasi ataupun pelayanan yang sebaik mungkin dengan berbasis digital. Dimana kemajuan teknologi khususnya di bidang informasi ini seharusnya menjadi pendorong bagi lembaga yang terkait khususnya perpustakaan dalam memenuhi kebutuhan informasi. Perpustakaan dituntut untuk mampu menyebarkan informasi dan memberikan kontribusi terhadap kehidupan sosial dan intelektual masyarakat. Salah satu cara yang dapat dilakukan adalah dengan memberikan layanan informasi kepada masyarakat. 
Dimana layanan informasi ini tentu harus mampu menarik masyarakat untuk memiliki keinginan mencari informasi melalui perpustakaan sebagai lembaga penyedia informasi.

Kegiatan kemas ulang informasi merupakan salah satu kegiatan yang menganalis suatu informasi yang nantinya akan disajikan ke dalam bentuk yang lebih cocok dan mudah dimengerti oleh masyarakat. Suatu informasi dapat dikatakan berguna apabila mampu memberi nilai pengetahuan bagi pemakainya, dan kemas ulang informasi merupakan kegiatan sekaligus layanan informasi yang dapat memberikan informasi kepada masyarakat dalam bentuk yang berbeda dan mudah diterima. Tidak terkecuali perpustakaan di PDDI LIPI ini, dimana dalam perkembangnya mulai beralih menjadi perpustakaan digital. Selain itu Kepustakaan PDDI LIPI Kawasan Bandung ini juga sudah mulai menerapkan kebijakan-kebijakan mengenai pengadaan koleksi berbasis digital dan pengolahan bahan koleksi menjadi digital, maka dari itu Kepustakaan PDDI LIPI Kawasan Bandung juga berupaya melakukan pengembangan, pelayanan informasi, dan kepustakaan di bidang teknologi. Oleh karenanya sebuah lembaga penyedia informasi seperti perpustakaan ini haruslah terus bekembang setiap saat demi tercapainya tujuan dari perpustakaan yaitu melayani dan memenuhi kebutuhan masyarakat akan informasi (Sukaesih, 2009).

Hal ini tentu menjadi alasan untuk perpustakaan agar dapat mengikuti zaman yang ada sekarang, yaitu dengan menjadi perpustakaan digital. Dimana dalam perpustakaan digital ini segala macam kegiatannya dilakukan secara digital, baik berupa pengadaan koleksi dengan digitalisasi ataupun pelayanan yang sebaik mungkin dengan berbasis digital. Seperti yang sudah disebutkan sebelumnya bahwa Kepustakaan PDDI LIPI Kawasan Bandung ini juga memiliki tujuan untuk dapat mengelola berbagai koleksi khususnya yang berkaitan dengan IPTEK di Bandung. Hal ini tentu menjadi tantangan tersendiri dalam melaksanakannya mengingat kawasan Bandung yang tidak kecil. Belum lagi factor-faktor lainnya seperti perkembangan teknologi dan informasi yang menuntut perpustakaan ini untuk berkembang menjadi lebih memadai. Berdasarkan pada hal yang telah disampaikan sebelumnya, maka 
dari itu penulis berminat untuk membahas mengenai bagaimana Kepustakaan PDDI - LIPI Kawasan Bandung ini dalam memberikan pelayanan kepada masyarakat di tengah genjarnya perkembangan teknologi dan ledakan informasi saat ini. Selain itu hal yang diperhatikan oleh penulis adalah untuk mengetahui bagaimana penerapan keilmuan pelayanan perpustaaan dalam konteks layanan informasi berbasis digital yang diterapkan di Kepustakaan PDDI - LIPI Kawasan Bandung.

\section{TINJAUAN PUSTAKA}

Kebutuhan akan informasi di era sekarang yang terus meningkat menjadi persoalan bagi lembaga-lembaga penyedia informasi untuk terus membuat sebuah inovasi agar mampu memberikan informasi yang relevan dengan dikemas semenarik mungkin. Atas dasar inilah penelitian ini dilakukan dengan mencari tahu bagaimana pengembangan layanan informasi yang berbasis digital di tengah gencarnya informasi.

\section{Perpustakaan}

Perpustakaan merupakan salah satu lembaga informasi yang cukup diketahui oleh masyarakat. Perpustakaan sendiri berasal dari kata pustaka yang memiliki arti sebagai buku, menurut Yusup dalam (Darlia, 2014) mengatakan bahwa perpustakaan merupakan sebuah ruangan atau juga sebuah tempat (dapat berupa bagian dari gedung atau gudang itu sendiri) yang didalamnya menyediakan koleksi berupa buku, naskah, koleksi dalam berbagai bentuk yang dipelihara dan disusun dengan sistem yang ada dan dimanfaatkan bukan untuk dijual. Berdasarkan penjelasan tersebut dapat dijelaskann bahwa pada dasarnya perpustakaan adalah sebuah lembaga atau tempat pengelolaan segala macam informasi yang terekam dan tersimpan dengan baik dalam bentuk tercetak ataupun non-tercetak. Selain itu menurut (Sulistyo-Basuki 2016) mengatakan bahwa perpustakaan adalah tempat untuk menyediakan bahan pustaka untuk kebutuhan informasi ilmiah, popular, maupun umum yang disediakan dalam bentuk cetak maupun non-cetak yang diatur dalam sistem. Maka dari itu berdasarkan penjelasan- 
penjelasan tersebut, maka secara tidak langsung dapat dikatakan bahwa perpustakaan adalah sebuah lembaga yang memiliki kewajiban untuk selalu menyediakan sumber-sumber informasi dalam berbagai bentuk dan dapat digunakan oleh siapa saja tanpa terkecuali.

\section{Perpustakaan Digital}

Seiring dengan perkembangan zaman saat ini, kita mulai mendengar berbagai macam istilah dari perpustakaan. Mulai dari istilah library without wall (perpustakaan tanpa dinding), virtual library (perpustakaan maya), digital library (perpustakaan digital), virtual katalog (katalog maya) baik dalam pembicaraan sehari-hari ataupun dalam literatur. Akan tetapi dari istilah yang telah disebutkan sebelumnya, perpustakaan menjadi istilah yang paling dikenal oleh orang-orang. Dimana perpustakaan digital pada dasarnya sama saja dengan perpustakaan pada biasanya, hanya ada beberapa prosedur yang membedakan. Perpustakan digital atau digital library merupakan sebuah bentuk dari perkembangan perpustakaan, berbagai kemudahan bagi para penggunannya untuk mengakses sumber-sumber elektronik dengan alat yang disediakan. Perpustakaan Digital adalah kata lain dari Digital Library. Dimana istilah ini digunakan untuk menjelaskan bagaimana konsep perpustakaan digital hampir sama dengan perpustakaan elektronik, perpustakaan maya, perpustakaan hibrida dan masih banyak lagi. Romi Satrio Wahono mengatakan bahwa perpustakaan digital sebagai sebuah perpustakaan yang dapat menyimpan data berupa buku (tulisan), suara, gambar dalam bentuk file elektronik dan mampu mendistribusikannya dengan menggunakan protokol elektronik tertentu melalui internet (Supriyanto, 2015).

Menurut Saffady dalam (Saleh, 2013) menjelaskan bahwa perpustakaan digital adalah perpustakaan yang mengelola semua atau sebagian substansi dari koleksi-koleksinya dalam bentuk komputerisasi sebagai bentuk alternatif, suplemen atau pelengkap terhadap cetakan konvensional dalam bentuk mikro material yang saat ini didominasi koleksi perpustakaan. Menurut Digital Library Federatiom di Amerika Serikat memberikan definisi mengenai perpustakaan digital sebagai sebuah organisasi atau lembaga yang menyedikan sumber-sumber informasi serta mendistribusikan, melestarikan, 
dan menjamin keberadaan koleksi dalam bentuk digital sepanjang koleksi tersebut dapat digunakan oleh masyarakat luas. Selain itu, menurut Gator Subroto dalam (Suharti 2019) perpustakaan digital merupakan Penerapan yang dilakukan dari perkembangan teknologi informasi sebagai sarana untuk mendapatkan, menyimpan, dan menyebarluaskan informasi dan ilmu pengetahuan dalam format yang berbentuk digital. Secara garis besar konsep dari perpustakaan digital ini merupakan jawaban dari keinginan masyarakat dalam kemudahan untuk mengakses informasi. Terdapat beberapa hal yang membedakan antara perpustakaan digital dengan perpustakaan konvensional, hal ini sesuai dengan yang dikatakan oleh Ted dan Large dalam (Prabowo, 2013) dimana perpustakaan digital memiliki karakteristik yang dapat membedakan, yaitu :

1) Perpustakaan digital harus dapat memuat informasi dalam bentuk digital.

2) Perpustakaan digital memiliki koleksi yang terorganisasi dan telah diseleksi sesuai dengan kebutuhan.

3) Perpustakaan digital harus memiliki jaringan.

4) Perpustakaan digital terdiri dari berbagai data lengkap dan juga metadata yang menggambarkan data tersebut.

5) Perpustakaan digital menekankan pada pentingnya stabilitas ketersediaan koleksi.

Berdasarkan ciri yang telah dijelaskan di atas, maka dapat dikatakan bahwa perpustakaan digital memiliki perbedaan dimana pada perpustakaan digital harus memiliki tempat untuk penyimpanan yang tidak memiliki batas pada format tertentu dan kemampuan dalam menyediakan akses info rmasi tanpa ada batasan ruang dan waktu. Selain itu dalam pengembangannya menjadi perpustakaan digital, ada beberapa elemen penting yang perlu diperhatikan antara lain yaitu :

1) Perpustakaan digital merupakan lembaga atau organisasi dengan tujuan khusus. Dimana pada umumnya tujuan dari perpustakaan digital adalah mengumpulkan, mengelola, menyimpan informasi atau bahan perpustakaan dalam format digital. 
2) Perpustakaan digital memiliki fungsi dan proses yang harus dilakukan untuk mencapai tujuan, visi dan misi yang diinginkan. Hal ini sudah termasuk dengan sumber daya yang perlu diadakan dalam proses pengembangan koleksi, membuka akses, serta dalam menyebarkan koleksi. Hal ini sudah termasuk dengan sumber daya yang perlu diadakan dalam proses pengembangan koleksi, membuka akses, serta dalam menyebarkan koleksi.

3) Perpustakaan digital berisikan koleksi elektronik yang meliputi dokumen teks lengkap, audio, video, image yang sebagian tidak dapat diwakili dalam bentuk cetak.

4) Perpustakaan digital memiliki akses jaringan yang ditempatkan pada satu tempat, hal ini nantinya dapat diakses melalui jaringan baik itu LAN, WAN, intranet maupun internet.

5) Perpustakaan digital memerlukan staf dengan kemampuan khusus, dimana seorang pustakawan selaku tenaga ahli tentu harus mempunyai kemampuan khusus yang berkaitan dengan pemanfaatan teknologi informasi untuk perpustakaan.

Pada dasarnya perpustakaan digital sama saja dengan perpustakaan biasa, yang membedakan dari perpustakaan digital adalah prosedur kerjanya yang berbasis komputer. Dimana pada perpustakaan digital ini para penggunanya dapat menggunakan sumber-sumber informasi yang ada tanpa harus terikat dengan jam operasional dari perpustakaan seperti jam kerja dan jam buka perpustakaan. Maka berdasarkan penjelasan sebelumnya, dapat disimpulkan bahwa perpustakaan digital ini merupakan sebuah wadah untuk dapat menyediakan sumber informasi untuk diseleksi, disusun, diterjemahkan, disebarkan dan dipelihara kesinambungan dari koleksi yang ada dalam bentuk format digital sehingga dapat tersedia kapan saja saat diperlukan oleh para penggunanya. Sebagaimana dengan penjelasan sebelumya, maka perpustakaan digital ini diharapkan dapat mempermudah siapa saja dalam mencari informasi khusunya di perpustakaan itu sendiri. Hal ini sesuai dengan manfaat yang dapat diberikan oleh perpustakaan digital itu sendiri. 


\section{Layanan Perpustakaan}

Layanan merupakan salah satu kegiatan yang dapat dikatakan cukup penting. Hal ini dikarenakan karena pada kegiatan layanan ini dilakukan langsung dengan para pengguna dan juga sebagai salah satu alat ukur sejauh mana perpustakaan dalam menjalankan perpustakaan nya. Yusup mengatakan bahwa layanan merupakan proses penyebarluasan segala macam informasi kepada masyarakat luas (Putra, 2017). Sedangkan Sukaesih mengatakan bahwa pelayanan adalah upaya untuk mempertemukan kebutuhan masyarakat melalui pemberdayaan sumber-sumber informasi kepada pengguna (Putra, 2017). Berdasarkan penjelasan tersebut, maka dapat diketahui bahwa sebuah pelayanan di perpustakaan menjadi salah satu aspek penting bagi perpustakaan khususnya dalam meningkatkan kualitasnya sebagai lembaga penyedia informasi yang baik. Perlu diketahui bahwa pelayanan yang baik adalah pelayanan yang dapat mencapai tujuannya dengan mengenai sasaran yang diinginkan sesuai dengan kebutuhan dan dapat mengoptimalkannya. Soetminah mengakatakan bahwa kegiatan pelayanan dapat dikatakan baik apabila memenuhi beberapa unsur, yaitu :

1. Cepat, artinya dapat memperoleh layanan dengan cepat tanpa perlu menunggu terlalu lama.

2. Tepat waktu, artinya orang yang membutuhkan layanan informasi dapat memperoleh kebutuhannya dengan tepat pada waktunya.

3. Benar, artinya kegiatan pelayanan dapat membantu untuk mendapatkan informasi sesuai dengan yang dibutuhkan.

(Putra 2017)

Selain faktor yang telah disebutkan sebelumnya, kegiatan pelayanan dapat dilakukan dengan baik sesuai dengan apa yang ingin dituju apabila didukung oleh aspek-aspek tertentu. Aspek pendukung tersebut adalah kualitas informasi atau koleksi yang dimiliki, dimana isi dari sebuah informasi atau koleksi yang ada dapat menjadi modal dasar dalam memberikan sebuah pelayanan bagi para penggunanya. Sebuah informasi atau koleksi yang baik harus memiliki kuantitas dan kualitas yang sama baiknya. Dimana kuantitas 
yang dimaksud berkaitan dengan jumlah informasi atau koleksi yang dimiliki cukup memadai, dan kualitas yang dimaksud adalah berkaitan dengan kebenaran, kemutakhiran, dan kelengkapan informasi atau koleksi yang ada. Selain itu aspek mengenai isi informasi, ada juga aspek lainnya yaitu fasilitas perpustakaan itu sendiri. Dimana fasilitas yang dimiliki oleh perpustakaan ini dapat menjadi penilaian bagaimana pelayanan yang diberikan apakah sudah maksimal atau belum. Fasilitas perpustakaan yang baik tentu memiliki kelengkapan yang mencakup lingkup layanan dan ketersediaan sarana prasanan untuk mendukung perpustakaan itu sendiri.

\section{Kemas Ulang Informasi}

Dongardive mengatakan bahwa kemas ulang informasi adalah suatu proses untuk meyeleksi, menganalisis, dan mengkosolidasikan dalam bentuk yang lebih tepat sehingga dapat digunakan oleh pengguna perpustakaan (Tupan 2015). Dimana dalam pembuatannya dibuat dalam bentuk digital atau media elektronik, seperti CD dan DVD. Selain itu juga dalam proses kemas ulang informasi mencakup kegiatan sebelum proses (reprocessing) dan pada saat pengemasan (packaging) (Fatmawati, 2009). Kegiatan tersebut mencakup penataan ulang dimulai dari menyeleksi berbagai informasi dari sumber berbeda, mendata informasi yang relevan, menganalis, mensistesis, dan menyajikan informasi yang sesuai dengan kebutuhan yang diinginkan oleh pengguna. Agar lebih tepat sasaran dan mampu memberikan manfaat yang lebih, Yoganingrum mengatakan bahwa kemasan informasi harus mampu mempertimbangkan karakteristik dari pengguna, yaitu :

1. Kebutuhan pengguna (terkait dengan isi, kemasan dan cara mengkomunikasikan).

2. Status pengguna (terkait pada wilayah, profesi, materi, usia, tingkat pendidikan).

3. Perilaku pengguna (umumnya berhubungan dengan status).

(Tupan 2015)

5. Proses Kemas Ulang Informasi 
Dongardive menjelaskan bahwa dalam prosesnya kemas ulang informasi memiliki beberapa metode yang dapat digunakan untuk memperoleh informasi yang spesifik dan sesuai dengan target (Tupan 2015). Secara umum metode ini mencakup pengumpulan, pengolahan, dan penerapan informasi serta perancangan dan pengemasan ulang informasi yang disesuaikan dengan permintaan. Berikut adalah beberapa metode kemas ulang informasi, yaitu:

1) Persiapan informasi singkat, yaitu menyiapkan informasi ringkas dari berbagai informasi terseleksi yang disiapkan oleh ahli informasi.

2) Analisis singkat, yakni menganalisis sumber-sumber informasi secara singkat untuk memenuhi target pengguna, isi, anggaran serta siklus hidup kemasan informasi.

3) Kriterian desain, yakni kemasan harus semenarik mungkin

4) Pemilihan pembawa pesan, yakni kemasan informasi harus mampu dirancang dalam berbagai format dan ukuran.

5) Produksi pembawa pesan, kemasan informasi harus dirancang dengan baik sebelum diproduksi.

6) Perencanaan sistem umpan balik, yakni perlu perencanaan yang matang dalam menanggapi umpan balik dan penilaian dari pengguna.

\section{METODE}

Menurut Sugiyono metode peneltian pada dasarnya merupakan cara ilmiah untuk mendapatkan data dengan tujuan dan kegunaan tertentu (Sugiyono 2017). Berdasarkan hal tersebut terdapat empat kata kunci yang perlu diperhatikan yaitu cara ilmiah, data, tujuan dan kegunaan. Metode yang digunakan dalam penelitian ini adalah metode kualitatif dengan pendekatan bersifat deskriptif. Metode ini yang merupakan suatu metode dalam penelitian status kelompok manusia, suatu objek, suatu set kondisi, suatu sistem pemikiran ataupun suatu kelas peristiwa pada masa sekarang. Dengan menggunakan metode ini peneliti bermaksud untuk menganilisis dan mendeskripsikan suatu gejala dan mengamati aspek-aspek tertentu yang berkaitan dengan masalah yang sedang diteliti oleh peniliti, peniliti 
juga berusaha mendeskripsikan kejadian dan peristiwa yang berkaitan tanpa memberikan perlakuan khusus terhadap peristiwa tersebut. Penelitian ini juga merupakan penelitian lapangan (field research) dengan menggunakan pendekatan kualitatif. Dimana penelitian lapangan merupakan penelitian yang dilakukan dengan mengumpulkan data atau informasi melalui pengamatan secara langsung pada objek penelitian.

Dengan menggunakan metode ini peneliti bermaksud untuk menganilisis dan mendeskripsikan suatu gejala dan mengamati aspekaspek tertentu yang berkaitan dengan masalah yang sedang diteliti oleh peneliti, peneliti juga berusaha mendeskripsikan kejadian dan peristiwa yang berkaitan tanpa memberikan perlakuan khusus terhadap peristiwa tersebut. Dalam proses analisis data hal pertama yang dilakukan adalah dengan mempelajari informasi atau data yang telah didapat, baik data yang didapat dalam wawancara, pengamatan ataupun dari studi terhadap dokumen-dokumen. Dimana keseluruhan data yang didapat akan dibuat klasifikasi yang disesuaikan dengan masalah dan tujuan dari penelitian, yang nantinya akan disesuaikan dengan pendekatan kualitatif ke dalam sebuah deskriptif untuk kemudian dianalisis sehingga memungkinkan untuk diambil kesimpulan. Untuk mendeskripsikan penelitian ini, peneliti menempuh langkah-langkah sebagai berikut :

a. Mempersiapkan instrumen data

Sebelum penelitian ini dilakukan ke lapangan, peneliti terlebih dahulu mempersiapkan beberapa pertanyaan untuk memudahkan dalam pengumpulan data.

b. Pengumpulan data

Selama penelitian di lapangan dilakukan, hal pertama yang di lakukan adalah pengumpulan data yang berhubungan dengan tingkat pemakaian Jurnal Kajian Informasi dan Perpustakaan serta mengetahui bagaimana mahasiswa dalam memenuhi kebutuhan akan informasi.

c. Klasifikassi data

Setelah melakukan penelitian langkah selanjutnya adalah pengklasifikasian 
data untuk memilih data yang berhubungan dengan permasalahan kemudian di kelompokan menjadi satu untuk dapat ditarik kesimpulan.

d. Analisis data

Setelah data yang didapat sudah terkumpul, maka akan dilakukan sebuah analisis data dengan pendekatan analogis logika dengan cara menjelaskan dan menarik keismpulan dengan bertitik pada hal-hal yang dipertanyakan.

e. Penarikan kesimpulan

Setalah pengumpulan data dan kemudian pada akhirnya akan ditarik sebuah kesimpulan serta menyantumkan saran-saran.

\section{HASIL DAN PEMBAHASAN}

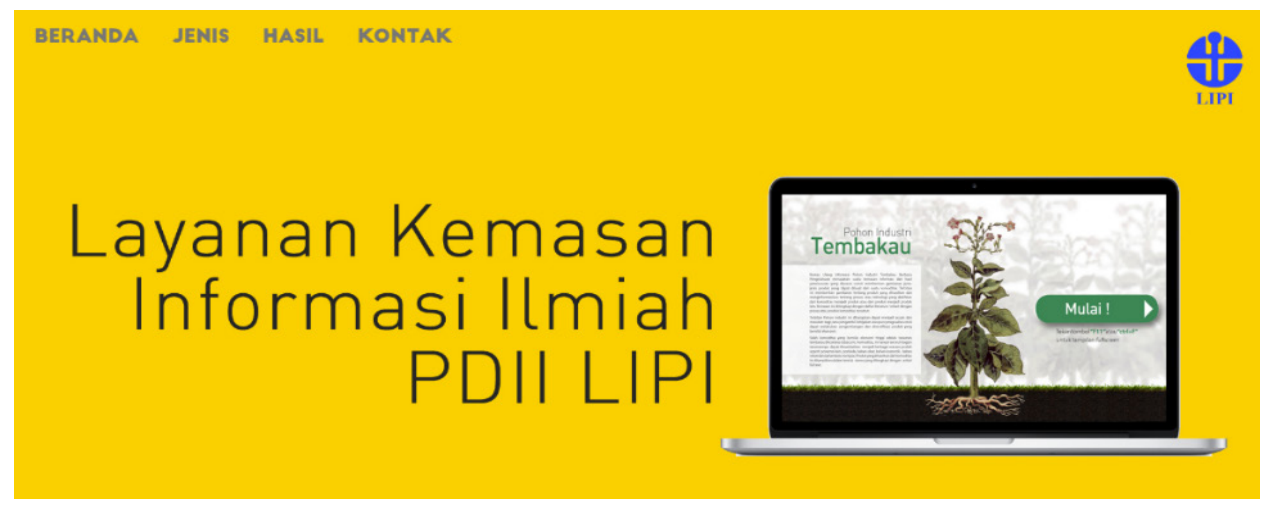

Gambar: Web Layanan Kemasan Informasi Ilmiah

Kegiatan layanan kemas ulang informasi di PDDI LIPI Bandung ini merupakan salah satu jasa yang diberikan oleh lembaga yang merupakan respon akan kebutuhan informasi bagi para pengguna informasi yang begitu responsif. Dimana sampai saat ini kegiatan layanan kemas ulang informasi dalam bentuk digital ini telah dikembangkan dengan sedemikian rupa untuk tetap dapat dinikmati oleh siapa saja dengan tetap memperhatikan perkembangan zaman. Hal ini tentu sesuai dengan semakin meningkatnya 
permintaan informasi dari masyarakat yang tentu memberikan dampak positif khususnya bagi badan usaha UKM yang telah menggunakan layanan kemas ulang informasi ini. Kepustakaan PDDI LIPI Kawasan Bandung yang terus menerus melakukan inovasi demi memberikan pelayanan terbaik kepada para penggunanya dengan menampilkan sebuah infromasi dalam tampilan yang menarik. Berdasarkan tinjauan yang dilakukan, terdapat beberapa layanan dalam bentuk digital yang dilakukan oleh Kepustakaan PDDI LIPI Kawasan Bandung yaitu kegiatan pohon industri dan buku elektronik dalam bentuk flipping book.

\section{Pohon Industri}

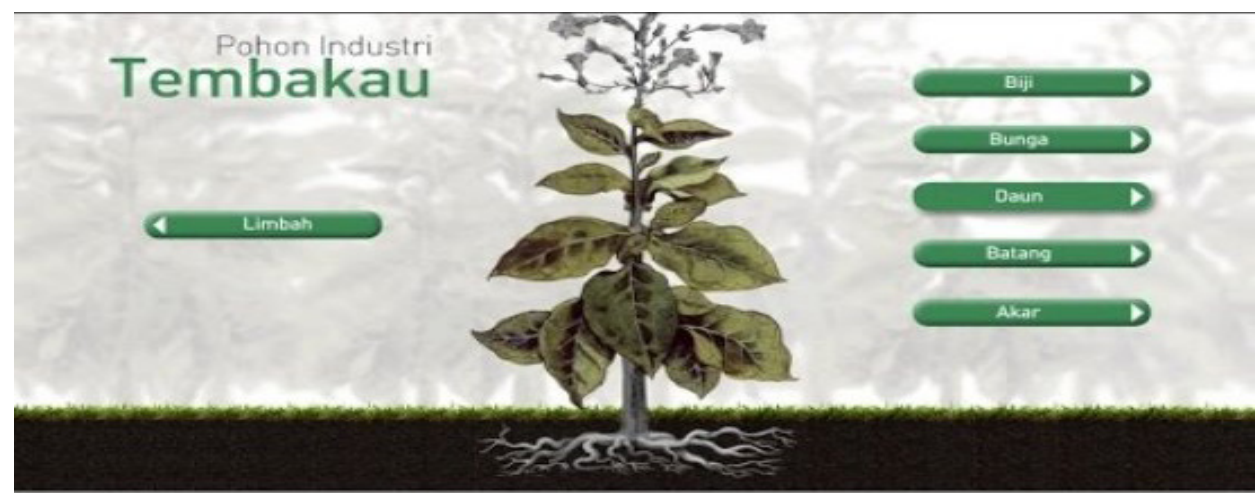

Gambar: Pohon Industri dengan tampilan digital

Pohon industri merupakan suatu terobosan yang dilakukan oleh Kepustakaan PDDI - LIPI Kawasan Bandung dalam upayanya untuk menjadi perpustakaan yang lebih baik. Dimana pohon industri ini adalah bentuk dari layanan informasi yang disajikan dengan memberikan sebuah kemasan informasi yang berisi ulasan, skema serta pemanfaatan terkait topik tertentu berdasakan sumber dari artikel yang ada pada jurnal-jurnal tertentu. Dimana dalam penyusunannya terdiri dari penjelasan, fungsi dan manfaat terhadap satu topik, yang nantinya akan disajikan dalam bentuk digital. Kepustakaan Kawasan Bandung PDDI - LIPI sendiri memiliki dua format yaitu tercetak dan digital. 


\section{Flipping Book}

Flipping book merupakan kegiatan alih media dari cetak menjadi digital dalam bentuk buku tiga dimensi (3D). Flipping book ini adalah bentuk dari tanggung jawab sekaligus kepeduliaan lembaga LIPI atas perkembangan ilmu pengetahuan di Indonesia. Hal ini berdasarkan atas pasal 2 Keputusan Kepala LIPI no 1026/M/2002, dimana UPT Balai Informasi Teknologi LIPI mempunyai tugas untuk melaksanakan pengembangan, pelayanan informasi teknologi dan kepustakaan bidang teknologi. Dalam pelaksanaannya, kegiatan ini sudah dilaksanalan sejak tahun 2015 dan sudah menjadi kebijakan dari LIPI ini sendiri untuk dapat memberikan informasi yang akurat karena isi dari flipping book ini adalah hasil penelitian yang dilakukan oleh LIPI. Kegiatan ini juga merupakan bentuk dari kegiatan alih media tercetak menjadi digital dalam upayanya menjadi perpustakaan yang lebih digemari oleh masyarakat. Hingga saat ini kegiatan digitalisasi koleksi dari cetak menjadi digital sudah dilakukan sebanyak kurang lebih 130 koleksi dan disediakan pada website khusus yang telah disediakan. Dalam kegiatan yang telah dilakukan oleh penulis, ada 5 tahapan yang harus dilakukan untuk dapat mencapai tahap alih media dari cetak menjadi bentuk digital. Berikut adalah 5 tahapan yang dilakukan dalam kegiatan alih media ini sebagai berikut :

1. Pemilihan Bahan Pustaka

Pada tahap pertama ini penulis diarahkan untuk menentukan koleksi yang akan dialih mediakan nantinya dari tercetak menjadi berbentuk digital. Dalam menentukan pilihan koleksi, penulis juga diarahkan untuk memahami isi dari koleksi yang dipilih.

2. Scanning Buku

Pada tahap ini dilakukan setelah menentukan koleksi yang telah ditentukan sebelumnya, kemuda penulis diarahkan untuk menuju alat scan. Dalam prosesnya scanning buku ini dilakukan secara bertahap dan setiap halamannya tidak boleh dilewatkan. Setalah selesai melakukan kegiatan scanning koleksi hasilnya akan diatur dalam format PDF, pemilihan format ini akan mempermudah tahapan selanjutnya. 


\section{Editing}

Pada tahap ini, koleksi yang sudah tersimpan dalam format PDF sebelumnya akan dilakukan editing untuk diperjelas serta merapikan bagian-bagian yang dirasa kurang tepat dan juga tidak lupa untuk pemberian logo LIPI sebagai bentuk pencegahan terhadap plagiarism. Proses editing ini dilakukan dengan menggunakan software aplikasi Adobe AcorbatPro.

4. Melakukan import file PDF menjadi buku elektronik (e-book)

Setelah melalui tahapan editing sebelumnya dengan menggunakan software Adobe AcrobatPro, kemudian koleksi yang telah diedit tersebut akan dilakukan pemindahan atau import untuk mengubah tampilan dari PDF menjadi buku digital. Pada tahap ini penulis didampingi oleh Bapak Dwiyanto Wahyu Ari Nugroho, S.Sos yang merupakan ahli dalam bidang analisis dokumentasi dan informasi. Selain itu aplikasi yang digunakan dalam tahap ini adalah aplikasi Flippingbook Publisher.

5. Menginput file pada website

Ini merupakan tahapan terakhir yaitu dengan menginput file yang telah melalui tahapan sebelumnya kemudian dipilih untuk disebarluaskan melalui website buku tiga dimensi LIPI yaitu www.ebook3d.bit.lipi.go.id, dimana dalam website ini kita dapat melihat hasil dari kegiatan alih media yang telah dilakukan oleh Kepustakaan PDDI - LIPI Kawasan Bandung.

Kegiatan membuat pohon industri ini merupakan salah satu jenis layanan yang diberikan berupa layanan kemasan informasi ilmiah yang bertujuan untuk meningkatkan daya komunikasi dari informasi ilmiah yang tersedia di Kepustakaan PDDI LIPI Kawasan Bandung untuk dapat digunakan oleh masyarakat pada umumnya. Selain itu dalam upayanya untuk menjadi perpustakaan yang lebih modern Kepustakaan PDDI LIPI Kawasan Bandung juga sudah melakukan kegiatan seperti alih media pada koleksi yang dimiliki. Dimana dalam konteks ini yang dimaksud adalah proses transformasi koleksi dari yang awalnya masih dalam bentuk cetak menjadi bentuk digital. Kegiatan pohon industri dan buku elektronik 
dalam bentuk flipping book ini dapat dikatakan sebagai salah satu layanan informasi yang diberikan dengan kemasan informasi yang menarik dan mengikuti perkembangan zaman. Akan tetapi dalam prosesnya bentuk kemasan informasi ini memerlukan beberapa unsur pendukung seperti SDM yang mempuni serta software yang mendukung. Dimana unsur kreativitas dalam mengemas informasi dengan baik dan penuh dengan inovasi atau ide dari pembuat merupakan faktor penting dari keberhasilan dalam layanan informasi di Kepustakaan PDDI LIPI Kawasan Bandung.

Dalam upanya untuk menjadi perpustakaan yang lebih modern, Kepustakaan PDDI LIPI Kawasan Bandung selalu berusaha untuk memberikan pelayanan informasi yang berbasis digital dengan memberikan inovasi-inovasi terbaru. Hal ini juga merupakan upaya untuk melestarikan koleksi dalam bentuk digital, dimana dalam praktiknya Kepustakaan PDDI LIPI Kawasan Bandung ini sudah melakukan upaya seperti dalam hal pengadaan koleksi yang sudah mulai dilakukan dengan yang berbasis digital ataupun melakukan kegiatan pelayanan seperti halnya yang telah disebutkan di atas. Dimana kegiatan yang dilakukan oleh Kepustakaan PDDI LIPI Kawasan Bandung dapat dikatakan upaya dalam meningkatkaan kuantitas dan kualitas layanan informasi khususnya untuk Kepustakaan PDDI LIPI Kawasan Bandung itu sendiri. Maka dari itu Kepustakaan PDDI LIPI Kawasan Bandung dituntut untuk selalu memberikan yang terbaik dengan membuat inovasi dalam bidang pelayanan informasi untuk memenuhi kebutuhan para pencari informasi, dimana inovasi yang dikeluarkan harus lebih kreatif dan inovatif. Hal ini tentu sesuai dengan semakin meningkatnya permintaan informasi dari masyarakat yang tentu memberikan dampak positif khususnya bagi badan usaaha UKM yang telah menggunakan layanan kemas ulang informasi ini.

Pengembangan layanan kemas ulang informasi berbasis digital ini tentu sudah sesuai dengan target yang ingin dituju dari adanya kemas ulang informasi ini. Dimana tujuan dari adanya layanan kemas ulang informasi ini adalah sebagai berikut : 
1. Menyajikan informasi dalam bentuk kemas ulang informasi yang menarik dan mudah diterima.

2. Menyediakan informasi dengan sistematis berdasarkan data penelitian yang sesuai dengan kebuthan pengguna.

3. Menyediakan sarana dan pentujuk dalam menyusun kemasan informasi.

4. Mengumpulkan informasi yang dapat dipercaya dari berbagai sumber.

5. Mengkaji ulang berbagai literatur dan dokumen yang telah dikumpulkan.

Selain hal yang telah dijelaskan sebelumnya, PDDI LIPI juga menyediakan berbagai paket informasi hasil dari pengembangan kemas ulang informasi. Diantaranya adalah paket informasi teknologi, informasi kilat atau informasi baru, pohon industri, panduan usaha, tinjauan literatur, fokus informasi Indonesia, dan film animasi.

\section{KESIMPULAN}

Kegiatan pengembangan kemas ulang informasi yang dilakukan oleh PDDI LIPI ini merupakan salah satu upaya lembaga untuk meningkatkan kuantitas serta kualitas yang terdapat di LIPI. Dimana melalui pengembangan kemas ulang informasi ini, lembaga yang bersangkutan secara tidak langsung dituntut untuk lebih kreatif dan inovatif dalam memberikan pelayanan jasa informasi khususnya dalam bentuk digital yang menarik dan sesuai dengan kebutuhan para penggunanya. Melalui proses dari kemas ulang informasi yang telah dilakukan secara sistematis, diharapkan setiap informasi yang disediakan oleh PDDI LIPI dapat ditelusuri, dibaca dan dimengerti dengan mudah. Terkait dengan kebutuhan informasi dari masyarakat, PDDI LIPI juga telah berupaya memberikan inovasi dalam bentuk paket informasi yang beragam. Mulai dari paket informasi teknologi, informasi kilat atau informasi baru, pohon industri, panduan usaha, tinjauan literatur, fokus informasi Indonesia dan film animasi. Kegiatan pengembangan layanan kemas ulang informasi ini merupakan bentu dari perkembangan zaman saat ini, dimana Kepustakaan PDDI LIPI kawasan Bandung berupaya untuk menjadi perpustakaan digital yang mampu memberikan informasi 
dengan baik. Hal ini sudah mulai dilakukan setiap kegiatan nya, mulai dari pengadaan koleksi dalam bentuk digital sampai dengan proses digitalisasi koleksi-koleksi yang dimiliki.

Kepustakaan PDDI LIPI kawasan Bandung merupakan salah satu perpustakaan yang sangat memperhatian perkembangan dibidang teknologi informasi, hal ini dapat dilihat dari adanya upaya pengembangan menjadi perpustakaan digital yang mutakhir. Salah satu upayanya adalah pengembangan layanan yang diberikan. Pengembangan layanan kemas ulang informasi dirasa cukup penting karena merupakan layanan yang dapat dinikmati oleh siapa saja, dimana saja dan kapan saja. Akan tetapi dalam prosesnya ini, PDDI LIPI tentu memperhatikan berbagai faktor yang dapat menghambat. Mulai dari penambahan sumber daya manusia yang memiliki kemampuan yang memadai. Karena tanpa adanya faktor tersebut, kegiatan pengembangan layanan kemas ulang informasi ini tentu akan terhambat. Kepustakaan PDDI LIPI kawasan Bandung juga harus lebih mampu melakukan branding mengenai keberadaan perpustakaan agar lebih dapat dikenal oleh masyarakat sekitar. Dimana hal bertujuan untuk dapat membuat masyarakat sekitar dapat lebih interaktif terhadap betapa pentingnya sebuah informasi dari sumber-sumber informasi yang terpercaya. Selain itu pengadaan koleksi juga harus lebih diperhatikan, tidak hanya terpaku pada bentuk dari kolesi yang mengharuskan dalam bentuk digital. Tetapi kualitas dari informasi yang terkadung di dalam koleksi tersebut dan juga kuantitas dari koleksi tidak hanya dalam bentuk cetak tetapi digital juga harus ditingkatkan.

\section{DAFTAR PUSTAKA}

Darlia, Lilis. 2014. "Pelayanan Perpustakaan Sebagai Sumber Belajar di SMP Negeri 4 Bolaang Uki Kecamatan Posigadan Kabupaten Bolaang Mongondow Selatan. Other thesis.” eprints. UNG. eprints.ung.ac.id. Fatmawati, Endang. 2009. "Kemas Ulang Informasi: Suatu Tantangan Bagi Pustakawan.” Majalah Media Pustakawan 29. 
Prabowo, Thoriq Tri. 2013. “Mengenai Perpustakaan Digital.” Fihris journal UIN SUKA 109-119.

Putra, Fauzi Eka. 2017. "Kegiatan layanan dalam penulusuran informasi di perpustakaan." Jurnal Iqra 48 - 65.

Saleh, Abdul Rahman. 2013. Pengembangan Perpustakaan Digital. Bogor: Rumah Q-ta .

Sugiyono. 2017. Metode Penelitian Kuantitatif, Kualitatif dan R\&D. Bandung: Alfabeta.

Suharti. 2019. "Perpustakaan Digital Pendukung E-Learning di Era Disrupsi." Buletin Perpustakaan Universitas Islam Indonesia 19-30.

Sukaesih. 2009. Modul Kuliah Jasa Layanan Informasi dan Perpustakaan

: Suatu Pengantar Teoritis dan Praktis. Bandung: Jurusan Ilmu Informasi Fikom Unpad.

Sulistyo-Basuki. 2016. Pengantar Ilmu Perpustakaan. Jakarta: PT Gramedia Pustaka Utama.

Supriyanto, Wahyu. 2015. "Pengembangan Sistem Layanan Perpustakaan Digital." Librana Jurnal Ilmu Perpustakaan dan Informasi 1-12.

Tupan. 2015. "KEMAS ULANG INFORMASI UNTUK PEMENUHAN KEBUTUHAN INFORMASI USAHA KECIL MENENGAH: INFORMASI USAHA KECIL MENENGAH: TINJAUAN ANALISIS DI PDII-LIPI." Jurnal Dokumentasi dan Informasi 111-123. 